\title{
Silicate bioweathering and biomineralization in lacustrine microbialites: ancient analogues from the Miocene Duero Basin, Spain
}

\author{
M. ESTHER SANZ-MONTERO*† \& J. PABLO RODÍGUEZ-ARANDA* \\ * Departamento Petrología y Geoquímica, Facultad de Ciencias Geológicas, UCM, 28040, Madrid, Spain \\ FInstituto de Geología Económica (CSIC-UCM), C/ Antonio Novais 2, 28040, Madrid, Spain
}

\begin{abstract}
The Miocene dolomite-chert microbialites studied here offer a complete record of the geochemical cycles of silicate weathering and the subsequent formation of secondary products. The microbialites were formed in lacustrine systems during the Miocene of the Duero Basin, central Spain. Mineralogical, chemical and petrographic results provide evidence of the mediation of microbes in early weathering and by-product formation processes. Irrespective of the composition, the surfaces of the grains were subject to microbial attachment and concomitant weathering. Palaeo-weathering textures range from surface etching and pitting to extensive physical disaggregation of the minerals. Extreme silicate weathering led to the complete destruction of the silicate grains, whose prior existence is inferred from pseudomorphs exhibiting colonial textures like those recognized in the embedding matrix. Detailed petrographic and microanalytical examinations of the weathering effects in K-feldspars show that various secondary products with diverse crystallinity and chemical composition can coexist in the interior of a mineral. The coexistence of by-products is indicative of different microenvironmental conditions, likely created by microbial reactions. Thus, the presence of varied secondary products can be used as a criterion of biogenicity. Intensive alteration of P-bearing feldspars suggests that mineral weathering may have been driven by the nutrient requirements of the microbial consortium involved in the precipitation of dolomite. The rock record provides useful information on mineral weathering mediated by microbes.

Keywords: silicate dissolution, microbial weathering, biomineralization, lake, dolomite.
\end{abstract}

\section{Introduction}

Weathering of silicates at the Earth's surface has major impacts on the environment, especially in relation to soil formation and the release of cations. Mineral weathering has broad implications for the global carbon budget as $\mathrm{Ca}$ and $\mathrm{Mg}$ cations form $\mathrm{Ca}-$ and/or Mg-carbonates, resulting in sequestration of atmospheric $\mathrm{CO}_{2}$ (Berner, Lasaga \& Garrells, 1983). Quartz, feldspar, plagioclase and phyllosilicates are among the most abundant silicates contributing to these reactions (Welch \& Ullman, 1992; Stucki, Bailey \& Gan, 1996; Rogers, Bennet \& Choi, 1998; Bennett, Rogers \& Choi, 2001; Sanz-Montero, Rodr '1guez-Aranda \& P'erez-Soba, 2009), and carbonates and sulphates are susceptible to considerable weathering also (Davis \& L "uttge, 2005; SanzMontero, Rodr'iguez-Aranda \& Calvo, 2006). Although weathering traditionally has been considered primarily a chemical and physical process, increasingly micro-organisms are seen as playing a significant role in these processes (Ehrlich, 1996; Ullman \&Welch, 2002). The majority of bacteria in sedimentary systems are attached to mineral and rock surfaces, forming biofilms and microbial mats (Fletcher \& Murphy, 2001). Microbes attach to mineral surfaces for a variety of reasons (Davis \& L"uttge,

Author for correspondence: mesanz@geo.ucm.es
2005), including the availability of nutrients (Rogers, Bennet \& Choi, 1998), protection, and as a base to undertake metabolic activities. Regardless of the cause for microbial attachment, mineral colonization promotes mineral dissolution and the formation of secondary mineral products (Urrutia \& Beveridge, 1994; Konhauser \& Ferris, 1996; Barker, Welch, \& Banfield, 1997; Welch, Barker \& Banfield, 1999; Dong, Kostka \& Kim, 2003; Sanz-Montero \& Rodríguez-Aranda, 2007).

Bacteria, when attached, have been shown to accelerate the dissolution of minerals by the production of excess $\mathrm{H}^{+}$and organic ligands and, in some cases, by the production of $\mathrm{OH}^{-}$, extracellular polymeric substances (EPS) and enzymes (Vandevivere et al. 1994; Barker et al. 1998; Benett, Rogers \& Choi, 2001). Welch, Barker \& Banfield (1999) found that under mildly acidic conditions, microbial extracellular polymers increase dissolution by up to several orders of magnitude compared to inorganic conditions.

Thus, bioweathering processes have been widely studied mostly in relation to rock weathering and subsequent soil formation in modern systems. In contrast, systematic analyses have not been conducted on modern microbial mats, and still less in their fossil counterparts, represented by microbialites. This study was carried out in order to analyse early silicate weathering mechanisms and subsequent production of 


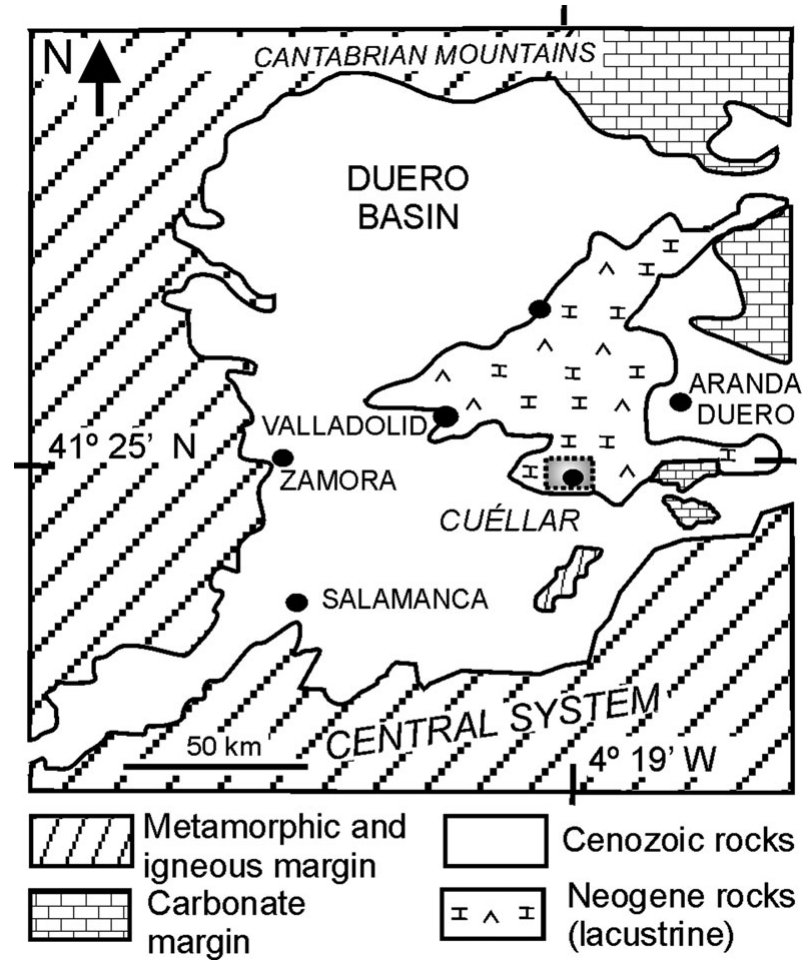

Figure 1. Location map of the study succession, near $\mathrm{Cu}$ 'ellar (area in dashed rectangle), in the central parts of the Duero Basin.

secondary phases (biominerals) by micro-organisms in microbial mats that thrived in Miocene lacustrine systems of the Duero Basin. Accordingly, this research expands the range of conditions conducive to silicate bioweathering to ancient saline lakes. The study complements other works focused on the potential activities of micro-organisms in the weathering of gypsum and biotite-bearing mudstone conducted by Sanz-Montero, Rodr'iguez-Aranda \& Calvo (2006) and Sanz-Montero, Rodr' '1guez-Aranda \& P'erez-Soba (2008) in correlatable Miocene dolo-microbialites of the Madrid Basin. The results of this study have implications for the role of microbial communities in the recycling of a range of minerals within dolomite deposits.

\section{Geological and sedimentary setting}

This research is centred on the early weathering processes undergone by silicate grains interlayered and/or interspersed throughout dolostone beds in dolomitebearing successions cropping out in the Duero Basin, located in the interior of the Iberian Peninsula (Fig. 1). The study succession, located near the village of $\mathrm{Cu}$ 'ellar, was deposited in the central parts of the basin and is included in the Intermediate lithostratigraphic unit (Middle Miocene). The stratigraphic section of the area is $80 \mathrm{~m}$ thick and mainly consists of dolostone, dolomarlstone, intrasedimentary and detrital gypsum, chert and secondary porous limestone (Fig. 2). Dolo-stone forms laterally continuous, tabular, centimetre-to decimetre-thick beds that can be superimposed in up to $20 \mathrm{~m}$ thick sequences (Fig. 2a, d). The beds, white to cream in colour, are porous and friable and occasionally include moulds of intrasedimentary gypsum aggregates filled in with calcite cements (Fig. 2b). The internal structure of the dolostone beds ranges from massive to vaguely laminate and locally is disrupted by millimetre-to centimetre-scale burrow traces (Fig. 2c). Burrows
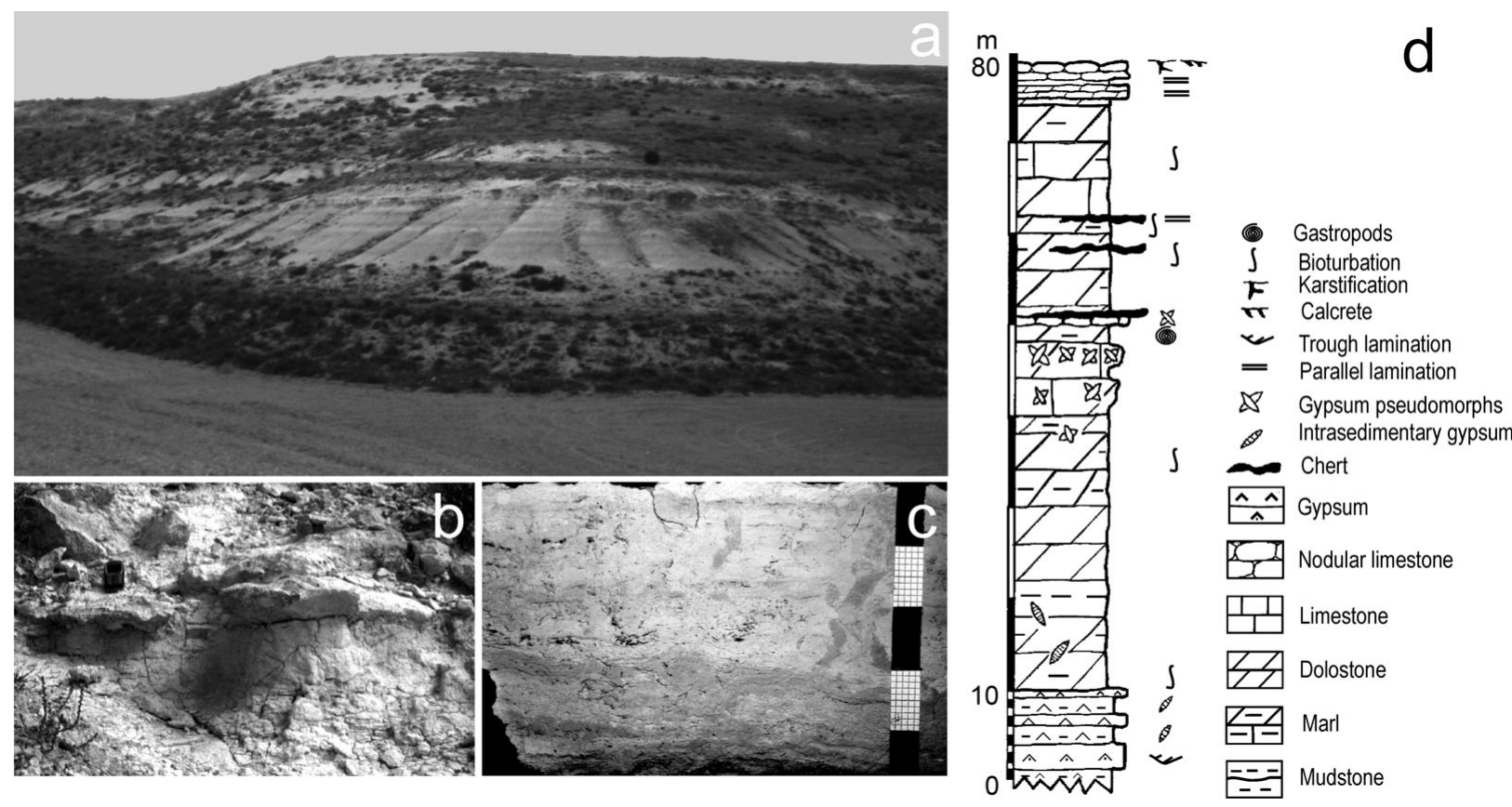

Figure 2. (a) General view of the horizontally-bedded sedimentary succession in the vicinity of Cu'ellar. Outcrop thickness is 50 m.(b) Outcrop photography of poorly indurated dolostone passing into an indurated limestone bed on which the mobile telephone rests for scale. (c) Hand specimen of dolostone showing a thin lamination disrupted by burrowing. Scale in centimetres. (d) Generalized sedimentary log of the studied microbialite-bearing succession. 
frequently occur as cylindrical tubes with meniscated back-filling structures possibly caused by feeding and dwelling activities of invertebrates (Rodr'iguezAranda \& Calvo, 1998). Commonly, fine-grained detrital grains are scattered throughout the facies. Some beds are composed of variable mixtures of dolomite and silica (opal-CT and quartz).

Based on facies analyses carried out in the study area, Sanz-Montero, Rodr'1guez-Aranda \& Garc'1a del Cura (2008) established a sedimentary model in mudflat-ephemeral saline lake complexes, where gypsum was the main evaporite precipitated. The lake deposits interfinger with terrigenous deposits towards the basin margins in accordance with a typical alluvial-saline lake concentric pattern characteristic of a hydrologic-ally closed basin (Armenteros et al. 2002).

Diagenetic evolution of the studied succession has led to a maximum depth of burial of over $100 \mathrm{~m}$ and has not recorded any metamorphic or hydrothermal event (Armenteros et al. 2002). Thus, the features recognized in the analysed rocks have been interpreted in terms of sedimentary and/or surficial diagenetic processes.

\section{Material and methods}

Standard petrographic analyses of twenty samples were used to describe the features of silicate weathering in dolomite and chert microfacies. Additionally, UV-fluorescence microscopy images of thin-sections were obtained with an Olympus BX51, equipped with a U-RFL-T power supply unit, to evaluate the presence and distribution of light hydrocarbons and organic matter in the samples.

For high-resolution textural analysis of the weathered silicates, thin-sections and fresh broken surfaces of previously air-dried samples were studied with scanning electron microscopy provided with Xray energy dispersive spectroscopy, SEM-EDS (JEOL JSM-840) and FE-SEM (JEOL JM-6400). Electronmicroprobe (EMP) quantitative spot analyses and elemental mappings of the samples were carried out in wavelength-dispersive mode, using a JEOL Superprobe JXA 8900-M equipped with four crystal spectrometers. Operating conditions were as follows: acceleration voltage of $20 \mathrm{kV}$, and probe current of 50 $\mathrm{nA}$, with variable counting times between 10 and 30 seconds and between 5 and 15 seconds, in peak and background, respectively. Beam diameter was between 2 and $5 \mu \mathrm{m}$ in order to minimize damage from the electron beam.

$\mathrm{X}$-ray diffraction (XRD) of the whole rock was used to determine mineral composition in powdered samples. A Philips X-ray diffraction system was operated at $40 \mathrm{kV}$ and $30 \mathrm{~mA}$, using monochromated $\mathrm{Cu}-\mathrm{K}_{\alpha}$ radiation. Semi-quantitative estimates of relative percentages of minerals from whole rock samples were made through measurement of intensity of the diffraction peaks by integration of the area. Orientated samples were also examined by X-ray diffraction for the determination of clay minerals in mudrocks.

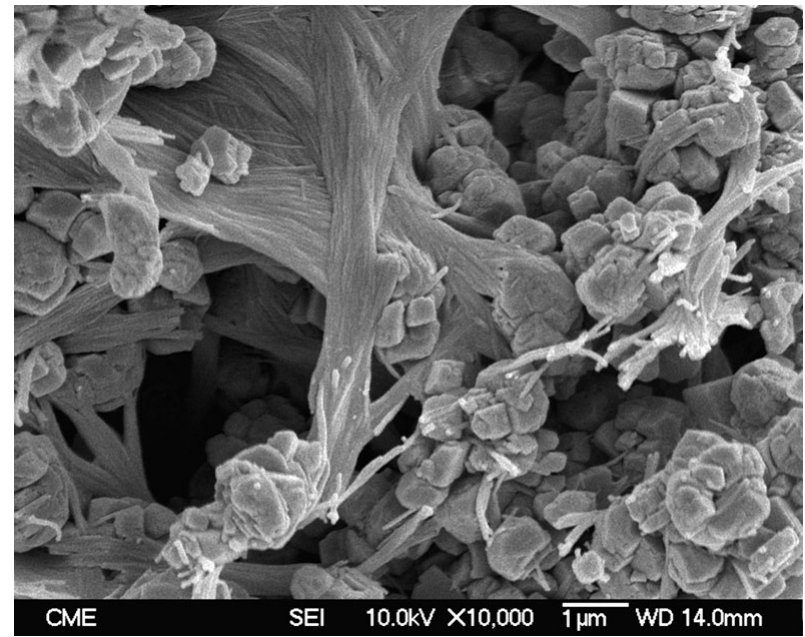

Figure 3. FE-SEM micrograph of a freshly broken sample showing porous dolomicrite crystals associated with C-rich films with fibrillar texture.

Total organic carbon (TOC) determinations were carried out in nine bulk samples. Carbon Isotope compositions were determined by measuring three separate fractions of the samples relative to high-purity, calibrated reference gas standards in the Stable Isotope Laboratories of the Royal Holloway University of London.

\section{Results}

\section{4.a. Dolostone: petrographic features and microbial origin}

Dolomite microfacies consist mainly of boundstone, characterized by shrub, clotted and filament-like micrite and microsparite. Fluorescence microscopy ob-servations reveal that the carbonate crystals fluoresce, which is related to the presence of organic matter within the dolomites. Under SEM, the texture of the dolomite is characterized by open clusters of micrometre-sized crystals that frequently are interwoven with bundles of organic substances (Fig. 3). Porous dolomite crystals are characterized by variable external morphologies and are often made of agglomerations of subcrystals separated by carbonaceous fibrils (Fig. 3). Commonly, dolomicrite exhibits distinctive spheroid hollow cores, which are outlined and highlighted by a thin fluorescent coat. According to Sanz-Montero, Rodr'iguez-Aranda \& $\mathrm{G}$ a $\mathrm{r}$ c '1a del Cura (2008), the spheroid crystals arose from the epicellular precipitation of dolomite on coccoid bacteria. Similar colonial structures, attributed to coccoid bacteria, are also finely preserved in chert (Fig. 4)

TOC determinations detect the presence of up to $0.94 \mathrm{wt} \%$ of organic carbon in the samples. The isotopic composition of the insoluble organic residue yielded $\delta^{13} \mathrm{C}_{\mathrm{PDB}}$ values between -26.47 and $-23.54 \%$, averaging $-24.94 \% \pm 0.15 \%$.

Data from Sanz-Montero, Rodr' 1 guez-Aranda \& Garc'1a del Cura (2008) indicate that the carbonate contains invariably poorly-ordered (av. 0.4) calcian 


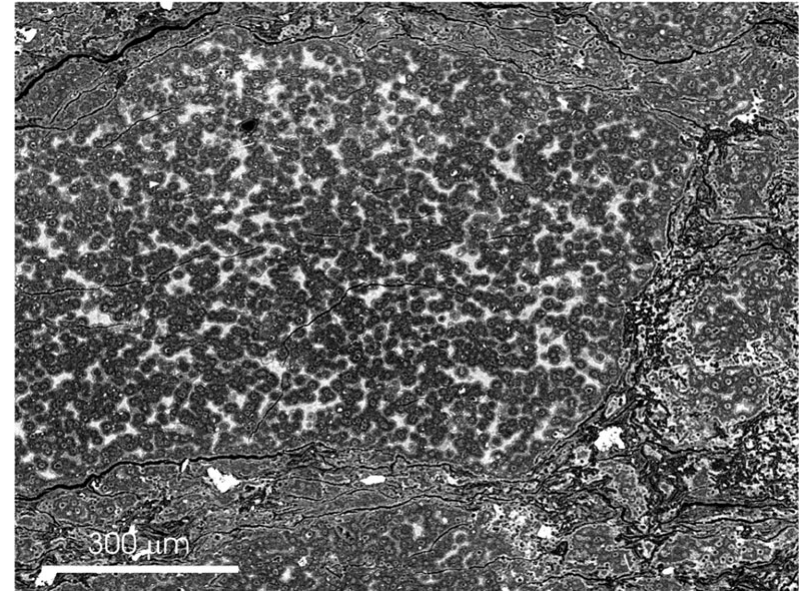

Figure 4. BSE-SEM micrograph of a polished thin-section from the silica beds showing clusters of cocci-like crystals interpreted as microbial colonies.

dolomites ranging in composition from 49 to $54 \mathrm{~mol}$ $\% \mathrm{CaCO}_{3}$ (av. $51 \%$ ). Carbon isotope signature of dolo-mites is negative, with average values ranging from-6.4 to $-3.6 \%$ PDB. $\delta^{18} \mathrm{O}_{\mathrm{PDB}}$ average values of the carbonate range from -1.3 to $+1.8 \%$.

\section{4.b. Silicate occurrences and composition}

Silicate minerals commonly occur as scattered siltsized grains through the chert and dolostone beds (Fig. 5). The silicates are mostly characterized by $\mathrm{X}$-ray and petrographic analyses as feldspar (K-feldspar and plagioclase), quartz and phyllosilicate (chiefly muscovite, and locally biotite and chlorite). Table 1 shows the detailed composition data of some examples of the silicate minerals, obtained through spot analyses carried out by the microprobe technique.

$\mathrm{K}$-feldspar grains are the most abundant feldspar in the deposits. They contain $\mathrm{P}_{2} \mathrm{O}_{5}(0.01-0.28 \mathrm{wt} \%)$ and $\mathrm{BaO}(0.09-0.42 \mathrm{wt} \%) . \mathrm{P}_{2} \mathrm{O}_{5}$ contents in plagioclases are low $(0.04-0.05$ wt \%), and they occasionally include scarce $\mathrm{BaO}$ (up to $0.05 \mathrm{wt} \%$ ). $\mathrm{P}_{2} \mathrm{O}_{5}$ and $\mathrm{BaO}$ concentration values in muscovite are commonly below

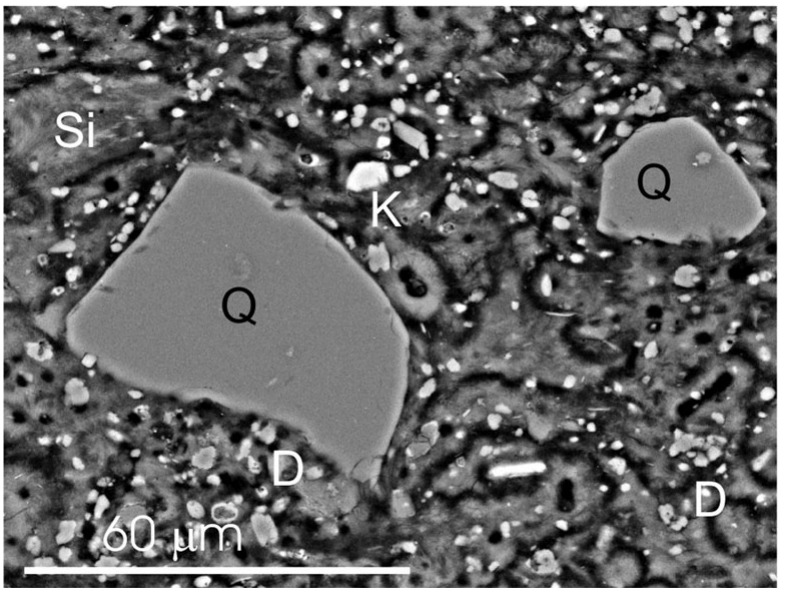

Figure 5. SEM micrograph of a polished thin-section showing floating quartz $(\mathrm{Q})$ and feldspar $(\mathrm{K})$ grains embedded within a silica matrix $(\mathrm{Si})$ with scattered dolomite crystals (D).

the detection limits. Quartz grains consist of $\mathrm{SiO}_{2}$ but also can contain minor quantities of $\mathrm{BaO}, \mathrm{SrO}$ and $\mathrm{SO}_{3}$, which are secondary products produced by weathering processes as explained below.

\section{4.c. The silicate-matrix interface}

Two types of silicate-matrix interfaces have been recognized. The first type was found in silica microbialites with scarce dolomite precipitates. Petrographic observations of these beds reveal that most of the silicates, irrespective of their mineralogy, occur coated by an irregular, generally continuous, fluorescent film (Fig. 6). In contrast, the silicate grains do not fluoresce, although frequently the coating and minerals mix at the interface. The up-to- $60 \mu \mathrm{m}$ thick films show a subtle lamination and a rough concentric arrangement around the grains (Fig. 7). The films may exhibit invaginations that conform to the irregularities of the corroded minerals. The film consists of a mesh of fibres that give it a cottony appearance. EDX and EMP microanalysis and elemental mappings indicate that films contain $\mathrm{Si}$ or $\mathrm{Al}$ and $\mathrm{Mg}$ as major constituents.

Table 1. Representative EMP analyses

\begin{tabular}{lcclcclllllll}
\hline \multicolumn{1}{c}{ (wt \%) } & $\mathrm{SiO}_{2}$ & $\mathrm{Al}_{2} \mathrm{O}_{3}$ & $\mathrm{FeO}$ & $\mathrm{MgO}$ & $\mathrm{CaO}$ & $\mathrm{Na}_{2} \mathrm{O}$ & ${ }_{2} \mathrm{~K}$ & $\mathrm{O}_{2} \mathrm{P}$ & $\mathrm{O}_{3} \mathrm{aO}$ & $\mathrm{SrO}$ & $\mathrm{SO}_{3}$ & Total \\
\hline K-feldspar & 61.09 & 19.91 & 0.11 & 0.05 & 0.25 & 0.30 & 15.4 & 0.01 & 0.09 & 0 & 0 & 97.21 \\
K-feldspar & 62.6 & 18.11 & 0 & 0.04 & 0.1 & 0.23 & 16.8 & 0.15 & 0.19 & 0.36 & 0.04 & 98.62 \\
Plagioclase & 61.07 & 20.28 & 1.91 & 2.19 & 2.73 & 8.7 & 0.8 & 0.04 & 0.03 & 0 & 0.09 & 97.84 \\
Plagioclase & 38.07 & 25.64 & 9.09 & 0 & 24.49 & 0 & 0 & 0.04 & 0 & 0 & 0 & 97.33 \\
Quartz & 99.66 & 0.12 & 0.06 & 0.04 & 0.03 & 0 & 0.01 & 0 & 0.15 & 0.66 & 0 & 100.7 \\
Quartz & 98.39 & 0.37 & 0 & 0 & 0.7 & 0 & 0 & 0 & 0 & 0 & 0.51 & 99.97 \\
Muscovite & 47.36 & 33.74 & 1.42 & 1.16 & 0.59 & 0.29 & 9.89 & 0 & 0 & 0 & 0.05 & 94.50 \\
Biotite & 43.68 & 7.07 & 8.57 & 13.5 & 7.02 & 0.14 & 0.98 & 0 & 0.02 & 0 & 0.08 & 81.06 \\
Dolomite & 6.57 & 1.19 & 0.35 & 16.1 & 22.6 & 0 & 0.09 & 0 & 0 & 0 & 0.4 & 47.30 \\
Dolomite & 0.63 & 0.06 & 0.09 & 16.8 & 27.4 & 0 & 0.01 & 0.07 & 0.05 & 0.12 & 0.4 & 45.63 \\
Calcite & 0 & 0 & 0.02 & 0.39 & 54.2 & 0 & 0 & 0 & 0.02 & 0.12 & 0.05 & 54.80 \\
Calcite & 0.89 & 0.2 & 0.1 & 2.68 & 50.8 & 0.01 & 0.01 & 0 & 0.17 & 0.26 & 0.17 & 55.29 \\
Film & 8.15 & 17.67 & 0.47 & 12.9 & 23 & 0 & 0.3 & 0 & 0.01 & 0 & 0.47 & 62.97 \\
Film & 43.72 & 4.18 & 1.64 & 15.8 & 0.08 & 0 & 0.54 & 0.06 & 0 & 0 & 0.06 & 66.08 \\
\hline
\end{tabular}

Representative EMP analyses (in wt \%) of different silicates and components associated with them. The sum of the oxides in the analyses of the carbonates and the films is low, this value is assumed to be mostly the $\mathrm{CO}_{2}$ content, which is not measurable by the EMP. 

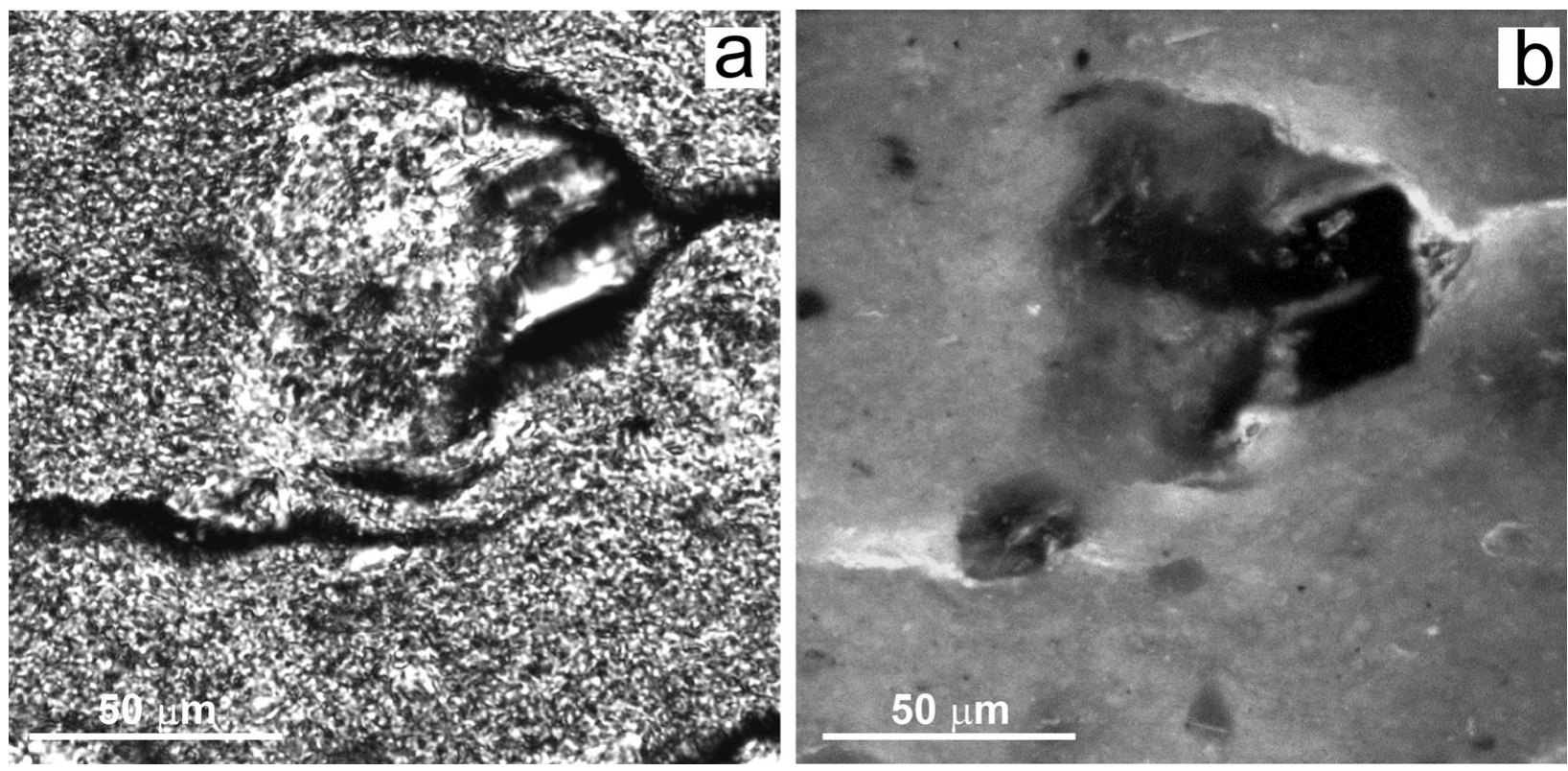

Figure 6. Photomicrographs of a weathered mica grain embedded within a silica matrix. (a) The transmitted light image shows a diffuse grain-matrix interface. (b) The fluorescence image highlights the presence of a fluorescent coating attached to the surface of the grain, which does not fluoresce. Weathered areas of the mineral show a moderate fluorescence.

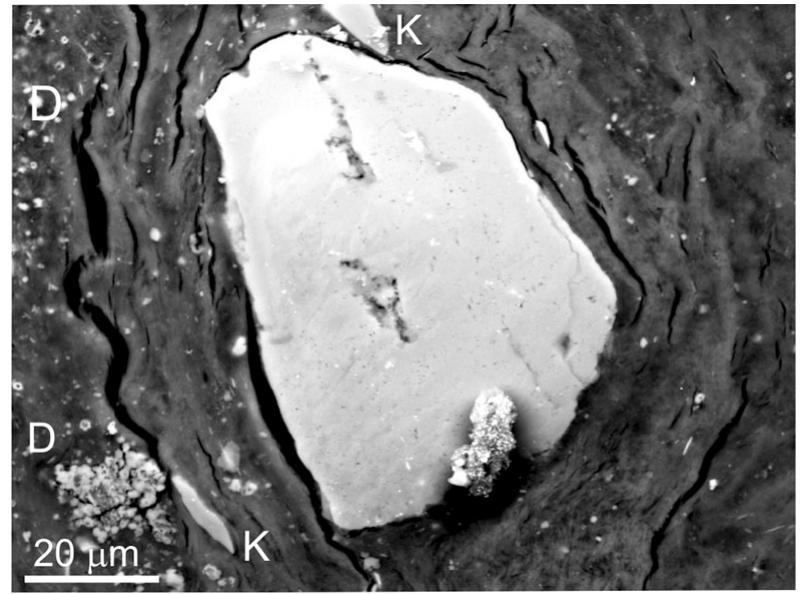

Figure 7. BSE-SEM micrograph of a polished thin-section showing a weathered K-feldspar coated by a roughly laminated film embedded within a silica matrix with scattered crystals of dolomite (D). Notice the presence of detached fragments from the silicate $(\mathrm{K})$ enclosed in the film.

The concentrations of these elements do not correspond to any known mineral phase. Variable amounts of $\mathrm{C}, \mathrm{Ca}, \mathrm{Fe}$ and $\mathrm{K}$ are frequently present. Minor P, S and, occasionally, Ba have also been detected (Table 1). Some minerals, chiefly carbonates, but also sulphates, can occur interspersed in the films (Fig. 7).

In the second type of interface, silicate grains occur embedded and corroded by coeval dolomite or silica rounded crystals that form the matrix (Fig. 8). Figure 8 a shows a quartz grain whose surface is corroded by rounded dolomite crystals up to $5 \mu \mathrm{m}$ in diameter. Around each single dolomite crystal, that may exhibit an inner core, a pit has developed. Pits are deeper when dolomite crystals occur aligned or grouped into clusters. In chert beds, similar clusters of rounded silica crystals, attributed to microbial colonies (SanzMontero, Rodr'iguez-Aranda \& Garc'ia del Cura, 2008), have been observed to corrode silicate grains (Fig. 8b). Along with dolomite and silica clusters, the grains occur coated by a tangle of rod-, filamentous and cocci-like structures that give the silicate surface a ropy appearance (Fig. 9).

\section{4.d. Weathering features on silicates}

The silicate minerals, including quartz, K-feldspar, plagioclase and mica, in the dolomite microbialites show a series of corrosion features that may range from shallow pits to deep depressions and can even result in the complete dissolution of the mineral. In a given sedimentary lamina, it has been observed that etching signatures are more intense in phyllosilicates and feldspars than in quartz (Fig. 10).

\section{4.d.1. Quartz weathering}

Quartz clasts show a variety of in situ weathering imprints distributed throughout the grains (Figs 8, 9, 10a). The surficial alteration has produced sharp edges and rough surfaces marked by inequalities, ridges and projections. Inside the grains, micrometre-sized pores coexist with deeply incised channels, which at several hundreds of micrometres in length, are observed to cross the crystals, frequently causing their division. Seen in greater detail, the channels consist of a net of coalescent grooves coming from different points of the surface (Fig. 10a). This pattern confers a serrated morphology to the outlines of the channels. Additional weathering imprints include the presence of detached splinters of quartz arranged around the grains. In some cases, the final sharp-cornered surface is, in turn, coated 


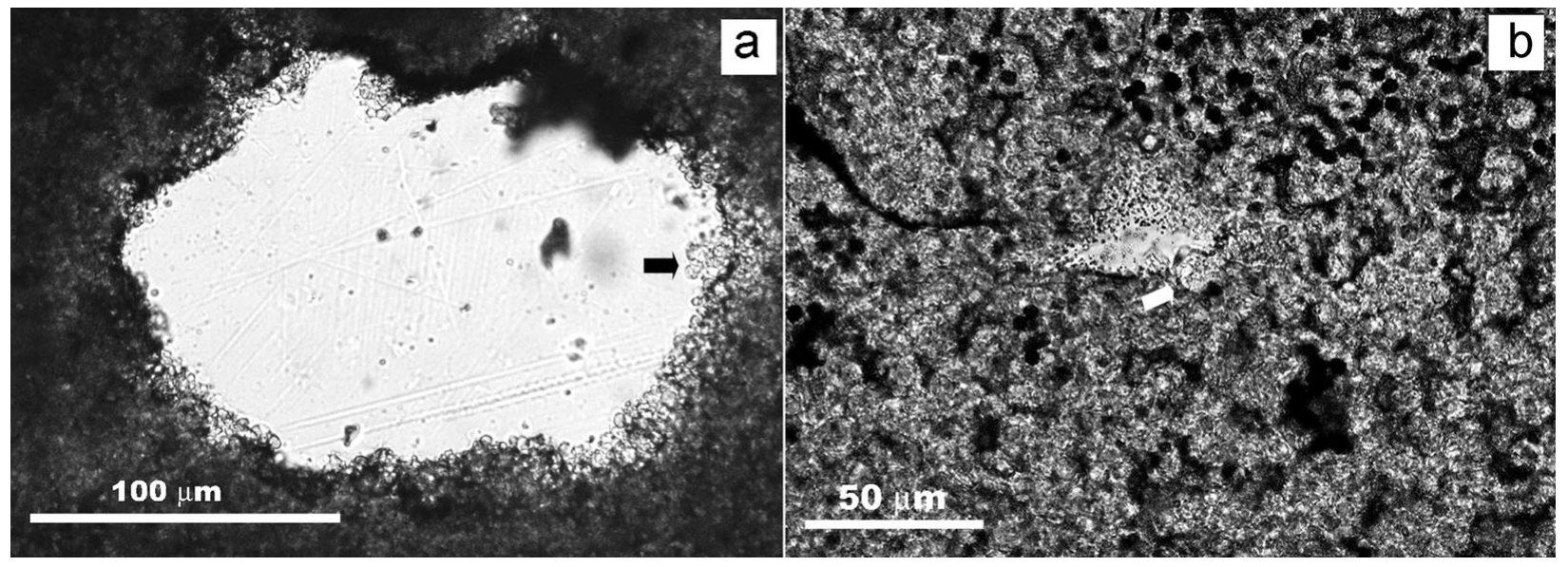

Figure 8. Transmitted light photomicrographs showing quartz grains embedded and corroded by rounded crystals. (a) Pits on the quartz surface are produced by dolomite crystals (some indicated by arrow). (b) Deep pits in a quartz grain produced around silica crystals (some indicated by arrow).

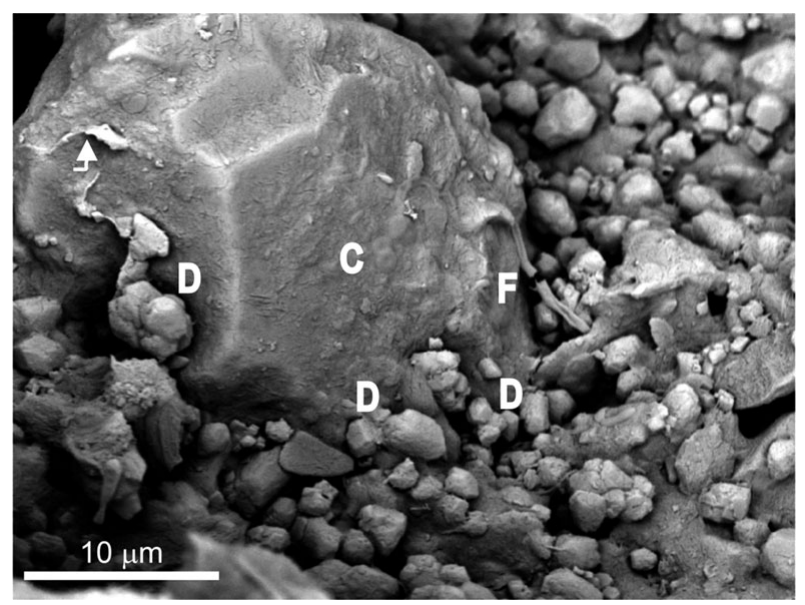

Figure 9. SEM micrograph of a freshly broken sample showing the weathered surface of a quartz grain embedded by a silica matrix with interspersed dolomite crystals. The surface of the grain is characterized by sharp-cornered edges, quartz strips (indicated by arrow), deep etched pits and associated dolomicrite (D), carbonaceous filaments (F) spanning the distances between the grain and the matrix, and cocci forms (C).

by a contorted film that reproduces the shape of the clasts. This is overlain by a coarsely laminated biofilm that presumably marks the former rounded surface of the clasts (Fig. 10a).

On the basis of EMP and EDS microanalysis carried out on the weathered surfaces it has been determined that alteration processes in quartz have been accompanied by the loss of $\mathrm{Si}$ with a concomitant gain of Al. A minor enrichment in S, $\mathrm{Mg}, \mathrm{Fe}, \mathrm{Ba}$ and $\mathrm{Sr}$ due to the presence of authigenic substances has also been found (Table 1). Frequently, clusters of micrometre-sized dolomite crystals occur associated with the dissolution features (Fig. 10a).

4.d.2. Phyllosilicate weathering

Muscovite is the most abundant and the bestpreserved phyllosilicate. Commonly, phyllosilicates occur as flakes less than $5 \mu \mathrm{m}$ in size, with the maximum grain size, up to $70 \mu \mathrm{m}$, corresponding to muscovite
(Fig. 6). The bigger grains are observed to be separated and exfoliated, preferentially along the cleavage planes, leaving detached flakes around them (Fig. 10b). Micropitting is also recognizable in phyllosilicates.

In chert beds, the weathered zone of phyllosilicates consists of an amorphous complex of $\mathrm{Si}, \mathrm{Al}, \mathrm{K}, \mathrm{Fe}$, $\mathrm{C}, \mathrm{Mg}$ and $\mathrm{Ca}$ and mineral strips (Fig. 6a). Conversely, in dolomite beds, dolomite and, locally, calcite occur mixed with the detached fragments of the weathered minerals.

\section{4.d.3. Plagioclase weathering}

Pitting and depressions on the surface, along with chipping and fragmentation of the grains are the most prominent weathering features observed in plagioclases, mostly Na-plagioclases (Fig. 10b). Weathering has commonly caused sharp-cornered surfaces that coexist with rounded pits. The abundance of sub-rectangular morphologies in the crystals suggests the alteration proceeded through preferential planes or discontinuities.

In chert beds, the weathered zone of plagioclases consists of an amorphous complex of $\mathrm{C}, \mathrm{Al}, \mathrm{Si}, \mathrm{Mg}, \mathrm{K}$, $\mathrm{Ca}$, with minor $\mathrm{P}, \mathrm{Fe}$, and occasionally $\mathrm{S}$. In general, plagioclase alteration entailed $\mathrm{Al}$ enrichment and Si depletion. In contrast, in dolomite beds, the weathered minerals are embedded and/or corroded by dolomite and minor calcite.

\section{4.d.4. $K$-feldspars weathering}

The weathering style in K-feldspars is characterized by distinctive etching textures, including large irregular galleries, pitting, chipping and fragmentation. The shapes and arrangement of the dissolution textures commonly reflect a structural control since they are aligned parallel to the cleavage planes of the silicate (Fig. 10c). In some cases, these processes have even caused the complete dissolution of the mineral. 

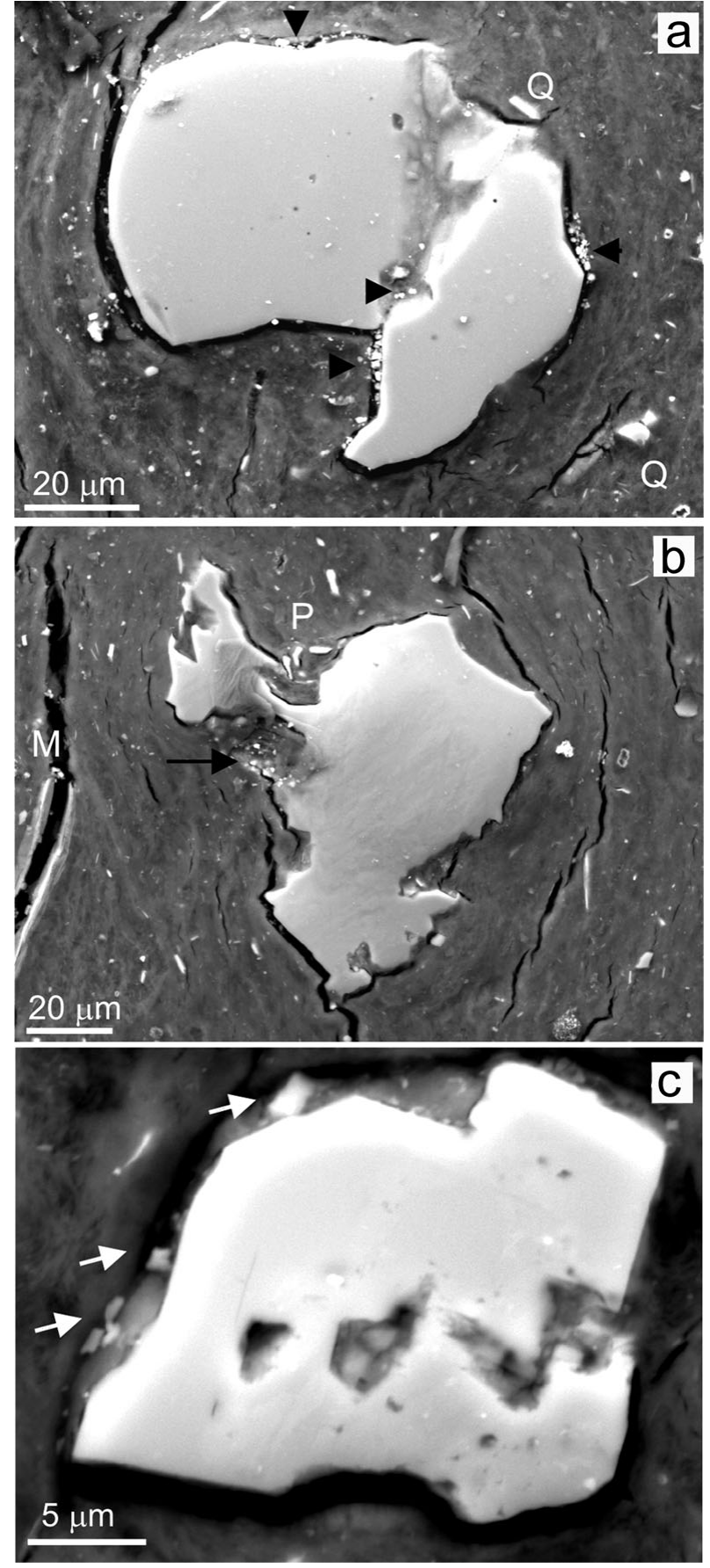

Figure 10. BSE-SEM micrographs of a polished thin-section from a given chert bed showing etching signatures in the more abundant silicate grains. (a) Weathered quartz grain exhibiting a surface marked by inequalities. Inside the grain a deeply incised channel is recognizable. Dolomite crystals associated with the dissolution marks are shown by arrows. Q indicates quartz splinters embedded in the coating. (b) The image shows weathering signatures in plagioclase, in the centre, and in mica (M) grains, to the left. Weathering has produced exfoliation in the mica, whereas the plagioclase exhibits sharp-cornered surfaces and pitting. Some detached fragments of the plagioclase are labelled by $\mathrm{P}$ and the arrow indicates the presence of dolomite crystals. (c) Gallery development in a Kfeldspar grain reflects a structural control of the weathering processes. The cotton-textured film arranged around and inside the grain embeds some dolomite grains (shown by arrows).
Figure 11 shows the weathering effects in a Kfeldspar that includes irregularly distributed $\mathrm{Na}-$ plagioclase microperthites and displays a wide range of alteration textures and products. Inside the silicate, the dissolution imprints are mixed up with different by-products, including C-rich substances (Fig. 11b). The results of 20 spot analyses carried out by EMP to characterize the different components distributed in a selected area of this altered grain (labelled with numbers 1 to 20 in Fig. 11b) are listed in Table 2. Analyses 1 to 11 correspond to the feldspar grain. For the numbered data, the first nine identify a K-feldspar and numbers 10 and 11 are typical of a Naplagioclase. Analyses 12 to 17 correspond to secondary products associated with the weathering textures that typically consist of pits and galleries. Pits range in size from a few to $100 \mu \mathrm{m}$ and the galleries are up to $200 \mu \mathrm{m}$ in length. Both textures show preferential development along the cleavage planes of the feldspar (Fig. 11b). Therefore, the outlines of the dissolution features fit well the outer surface of the grain that, in turn, is conditioned by the crystallographic structure of the mineral. Three different by-products have been identified, namely quartz (spots 12-13), a poorly crystallized phyllosilicate that has not been assigned to any commonly reported minerals (14-15) and barite (16-17). In addition, three calcite crystals corroding the mineral surface (18-19) and from the matrix (20) have been recognized.

Elemental mappings of the area (Figs 12,13) show a more precise distribution of the analysed elements, together with the $\mathrm{C}$ arrangement. The fluorescence image of the selected area (Fig. 12a) illustrates that the outlines of the dissolution features are fluorescent while the silicate grain and the secondary products are not.

Micrographs and analyses reveal that the feldspars have undergone an intensive alteration resulting in fragment detachment, dissolution, creation and enhancement of structural discontinuities. Compositionally, the $\mathrm{K}$-feldspar contains more $\mathrm{P}_{2} \mathrm{O}_{5}$ and $\mathrm{BaO}$ than the Naplagioclase. Spot analyses have also detected the occasional presence of $\mathrm{SO}_{3}$ in these minerals (Table 2). The selective association of $\mathrm{S}$ with the carbonate matrix and with the weathering textures (Fig. 13) indicates that it was incorporated into the silicates during the alteration processes. The dissolution features in the feldspar may remain partially empty but most of them include secondary products. Thus, approximately $10 \%$ of the mapped silicate surface (Figs 11b, 13) is covered by silica presumably released by the feldspar and subsequently precipitated in the newly produced spaces. This silica contains minor amounts of $\mathrm{Al}_{2} \mathrm{O}_{3}, \mathrm{~K}_{2} \mathrm{O}$ and $\mathrm{BaO}$, likewise derived from the feldspars, along with $\mathrm{SO}_{3}$ related to the weathering mechanisms (Table 2). $\mathrm{Al}_{2} \mathrm{O}_{3}$-rich silicates (phyllosilicates) may occur interlocked with silica. Barite $\left(\mathrm{BaSO}_{4}\right)$ i s another by-product that occurs throughout the feldspar, preferentially accumulated in pits. Barite consists of up to $50 \mu \mathrm{m}$ subidiomorph crystals which contain $\mathrm{SrO}$ and, commonly, are associated with $\mathrm{C}$ and other 

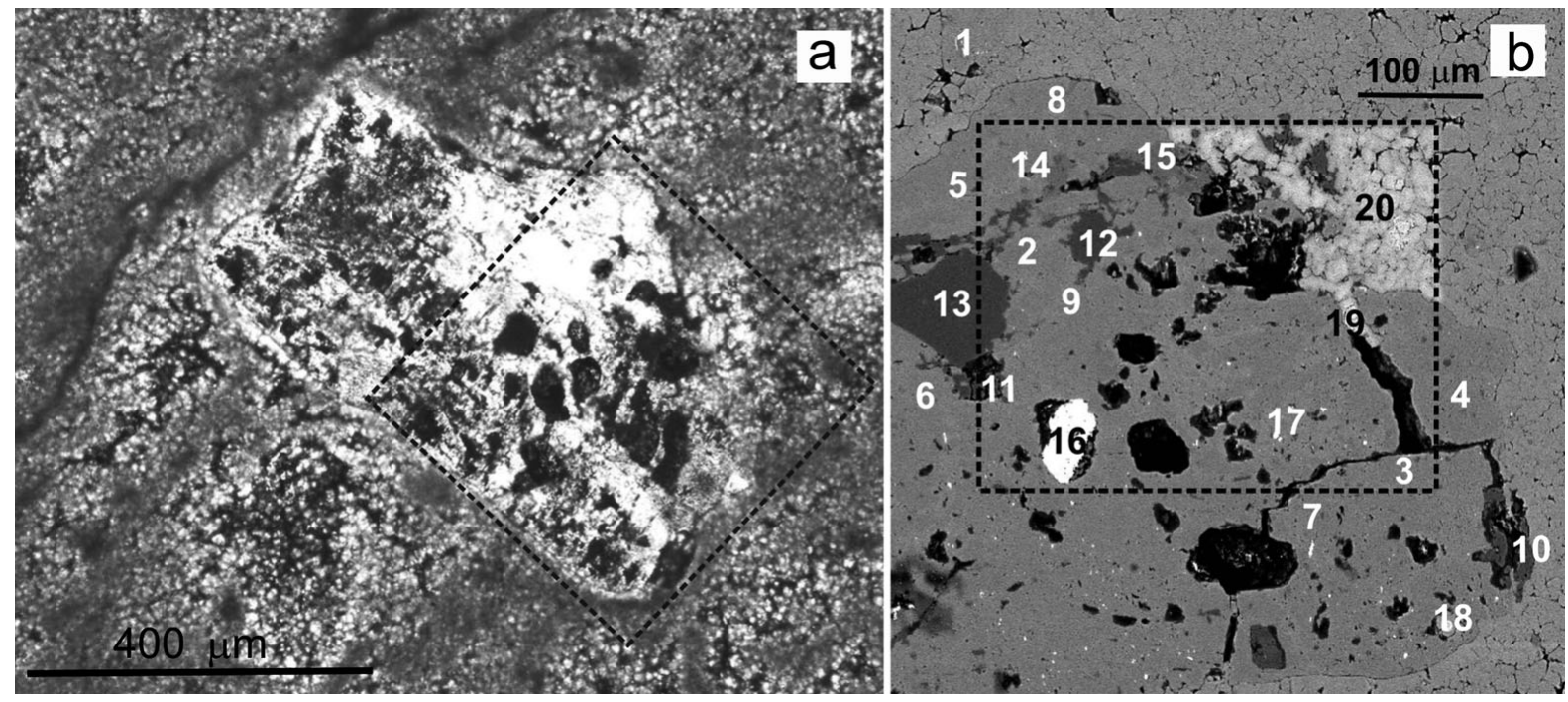

Figure 11. Micrographs of a polished thin-section illustrating the weathering effects in a K-feldspar grain from a microbialite bed.(a) Transmitted light photomicrograph of the feldspar entangled in a mesh of dolomite filaments. Weathering marks such as pits and galleries are distributed throughout the grain. (b) BSE-SEM magnified image of the area shown in dashed rectangle in (a), rotated $45^{\circ}$ anticlockwise, showing diverse weathering textures and the presence of secondary products. The numbers indicate the location of the spot analyses listed in Table 2. Elemental maps of the area in rectangle are shown in Figures 12 and 13. Whitening of the carbonates inside the mapped area was caused by the electron beam.

components (Figs 12b, 13). Other elements that can be recognized in relation to the dissolution imprints are $\mathrm{C}$ and $\mathrm{Mg}$. These elements frequently occur associated with, but not forming part of, carbonate minerals. The distribution partner of $\mathrm{C}$ also correlates well with the fluorescence observed in the weathering traits (Fig. 12), which corroborates that the fluorescence in these facies is caused by the presence of organic substances.

Table 2. EMP analyses of the weathered feldspar and the secondary products shown in Figure 11b

\begin{tabular}{|c|c|c|c|c|c|c|c|c|c|c|c|}
\hline \multirow[b]{2}{*}{$(w t \%)$} & \multicolumn{9}{|c|}{ K-feldspar } & \multicolumn{2}{|c|}{ Plagioclase } \\
\hline & 1 & 2 & 3 & 4 & 5 & 6 & 7 & 8 & 9 & 10 & 11 \\
\hline $\mathrm{SiO}_{2}$ & 63.71 & 63.26 & 63.17 & 62.96 & 62.85 & 62.68 & 63.96 & 63.54 & 63.67 & 69.66 & 64.60 \\
\hline $\mathrm{Al}_{2} \mathrm{O}_{3}$ & 18.85 & 18.97 & 18.89 & 18.97 & 19.13 & 18.49 & 18.95 & 19.13 & 18.89 & 21.05 & 19.82 \\
\hline $\mathrm{FeO}$ & 0.0 & 0.0 & 0.0 & 0.0 & 0.0 & 0.0 & 0.01 & 0.06 & 0.0 & 0.07 & 0.09 \\
\hline $\mathrm{MgO}$ & 0.0 & 0.01 & 0.0 & 0.0 & 0.0 & 0.0 & 0.04 & 0.02 & 0.01 & 0.19 & 0.25 \\
\hline $\mathrm{CaO}$ & 0.76 & 0.10 & 0.15 & 0.07 & 0.59 & 0.69 & 0.51 & 0.04 & 0.08 & 0.05 & 0.13 \\
\hline $\mathrm{Na}_{2} \mathrm{O}$ & 0.28 & 0.61 & 0.63 & 0.60 & 0.23 & 0.51 & 0.0 & 0.0 & 0.0 & 10.51 & 9.52 \\
\hline $\mathrm{K}_{2} \mathrm{O}$ & 16.53 & 15.86 & 15.87 & 15.71 & 16.18 & 16.03 & 18.95 & 15.97 & 15.84 & 0.46 & 0.11 \\
\hline $\mathrm{TiO}_{2}$ & 0.10 & 0.10 & 0.0 & 0.0 & 0.0 & 0.10 & 0.0 & 0.0 & 0.0 & 0.0 & 0.0 \\
\hline $\mathrm{P}_{2} \mathrm{O}_{5}$ & 0.0 & 0.11 & 0.19 & 0.18 & 0.0 & 0.15 & 0.0 & 0.0 & 0.0 & 0.04 & 0.05 \\
\hline $\mathrm{BaO}$ & 0.22 & 0.0 & 0.22 & 0.19 & 0.42 & 0.27 & 0.02 & 0.24 & 0.18 & 0.05 & 0.0 \\
\hline $\mathrm{SO}_{3}$ & 0.03 & 0.0 & 0.0 & 0.0 & 0.0 & 0.0 & 0.03 & 0.03 & 0.01 & 0.08 & 0.03 \\
\hline Total & 99.81 & 98.95 & 99.57 & 99.30 & 98.88 & 98.33 & 99.74 & 99.21 & 98.67 & 101.48 & 95.95 \\
\hline
\end{tabular}

(b) EMP analyses of secondary products

\begin{tabular}{|c|c|c|c|c|c|c|c|c|c|}
\hline \multirow[b]{2}{*}{ (wt \%) } & \multicolumn{2}{|c|}{ Quartz } & \multicolumn{2}{|c|}{ Phyllosilicate } & \multicolumn{2}{|c|}{ Barite } & \multicolumn{3}{|c|}{ Calcite } \\
\hline & 12 & 13 & 14 & 15 & 16 & 17 & 18 & 19 & 20 \\
\hline $\mathrm{SiO}_{2}$ & 98.80 & 98.85 & 51.91 & 38.47 & 0.74 & 0.17 & 0.22 & 0.21 & 0.93 \\
\hline $\mathrm{Al}_{2} \mathrm{O}_{3}$ & 0.05 & 0.05 & 40.78 & 35.02 & 2.81 & 3.26 & 0.14 & 0.11 & 0.25 \\
\hline $\mathrm{FeO}$ & 0.0 & 0.0 & 0.33 & 1.40 & 0.0 & 0.0 & 0.0 & 0.02 & 0.04 \\
\hline $\mathrm{MgO}$ & 0.0 & 0.0 & 1.42 & 0.99 & 0.09 & 0.06 & 0.29 & 0.26 & 0.57 \\
\hline $\mathrm{CaO}$ & 0.0 & 0.0 & 0.21 & 0.04 & 0.08 & 0.05 & 55.06 & 35.08 & 35.39 \\
\hline $\mathrm{Na}_{2} \mathrm{O}$ & 0.0 & 0.0 & 0.14 & 0.0 & 0.27 & 0.0 & 0.02 & 0.0 & 0.02 \\
\hline $\mathrm{K}_{2} \mathrm{O}$ & 0.03 & 0.0 & 8.72 & 10.85 & 0.13 & 0.11 & 0.39 & 0.14 & 0.39 \\
\hline $\mathrm{P}_{2} \mathrm{O}_{5}$ & 0.0 & 0.0 & 0.0 & 0.0 & 0.0 & 0.0 & 0.06 & 0.0 & 0.0 \\
\hline $\mathrm{BaO}$ & 0.0 & 0.05 & 0.29 & 0.0 & 61.93 & 57.98 & 0.0 & 0.02 & 0.02 \\
\hline $\mathrm{SrO}$ & 0.0 & 0.0 & 0.0 & 0.0 & 1.25 & 1.11 & 0.11 & 0.0 & 0.0 \\
\hline $\mathrm{SO}_{3}$ & 0.09 & 0.04 & 0.23 & 0.0 & 34.40 & 11.97 & 0.23 & 0.10 & 0.09 \\
\hline Total & 98.89 & 98.99 & 104.03 & 86.87 & 101.65 & 74.72 & 56.51 & 35.95 & 37.42 \\
\hline
\end{tabular}




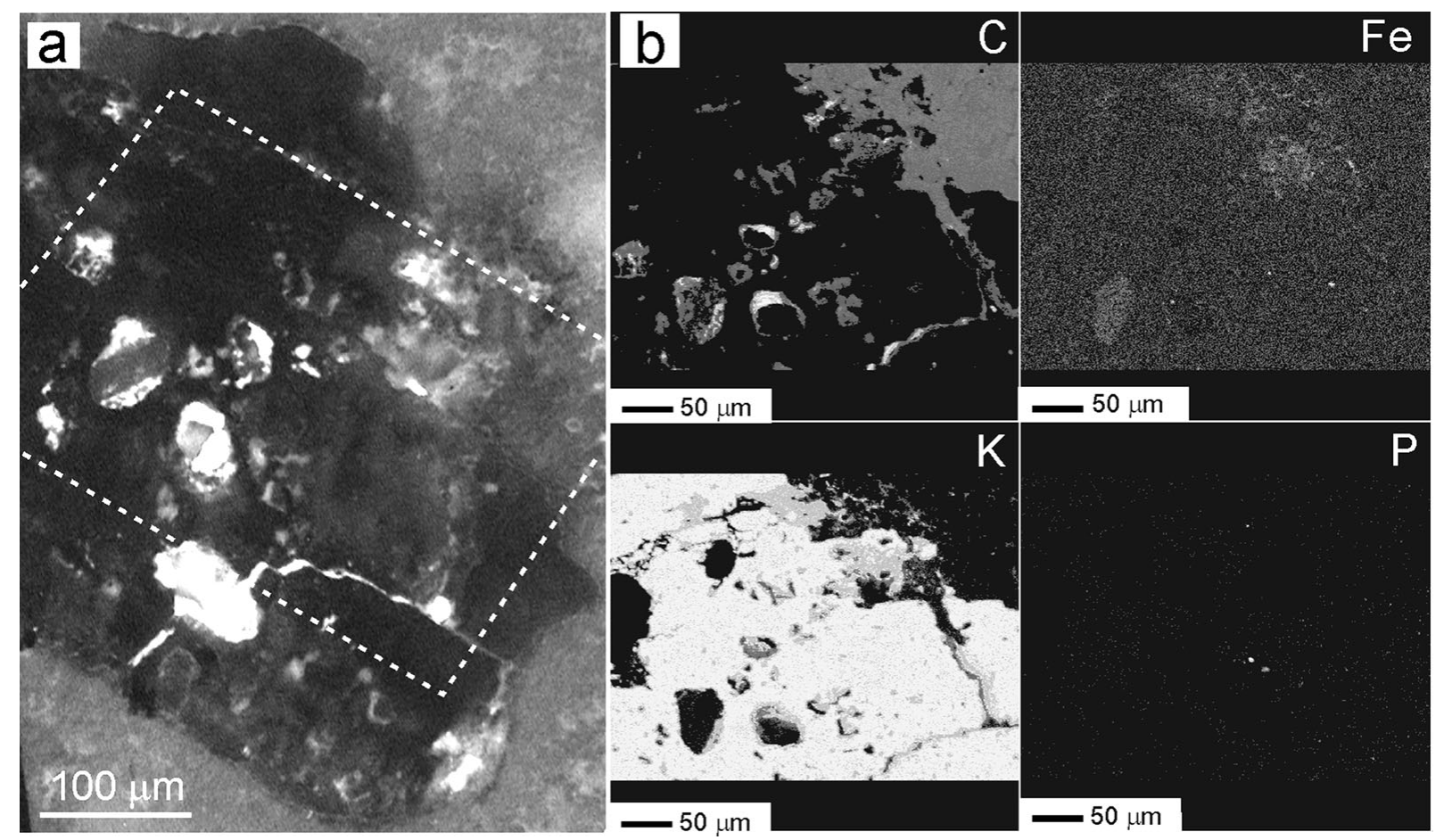

Figure 12. (a) UV fluorescence micrograph of the area in box shown in Figure 11a. The outlines of the dissolution marks fluoresce notably, whereas the feldspar and the secondary products do not. Boxed area corresponds to the mapped area shown in (b), although rotated $45^{\circ}$ anticlockwise. (b) Elemental mapping with the EMP technique showing the content variations of $\mathrm{C}, \mathrm{Fe}, \mathrm{K}$ and $\mathrm{P}$ in the weathered feldspar framed by a box in Figure 11b. Notice the carbon distribution and the fluorescence pattern inside the grain are positively correlated. $\mathrm{Fe}$ is associated with the alteration products. $\mathrm{K}$ decreases in the weathered fronts. $\mathrm{P}$ is scattered throughout the area. See http://journals.cambridge.org/geo for a colour version of this figure.

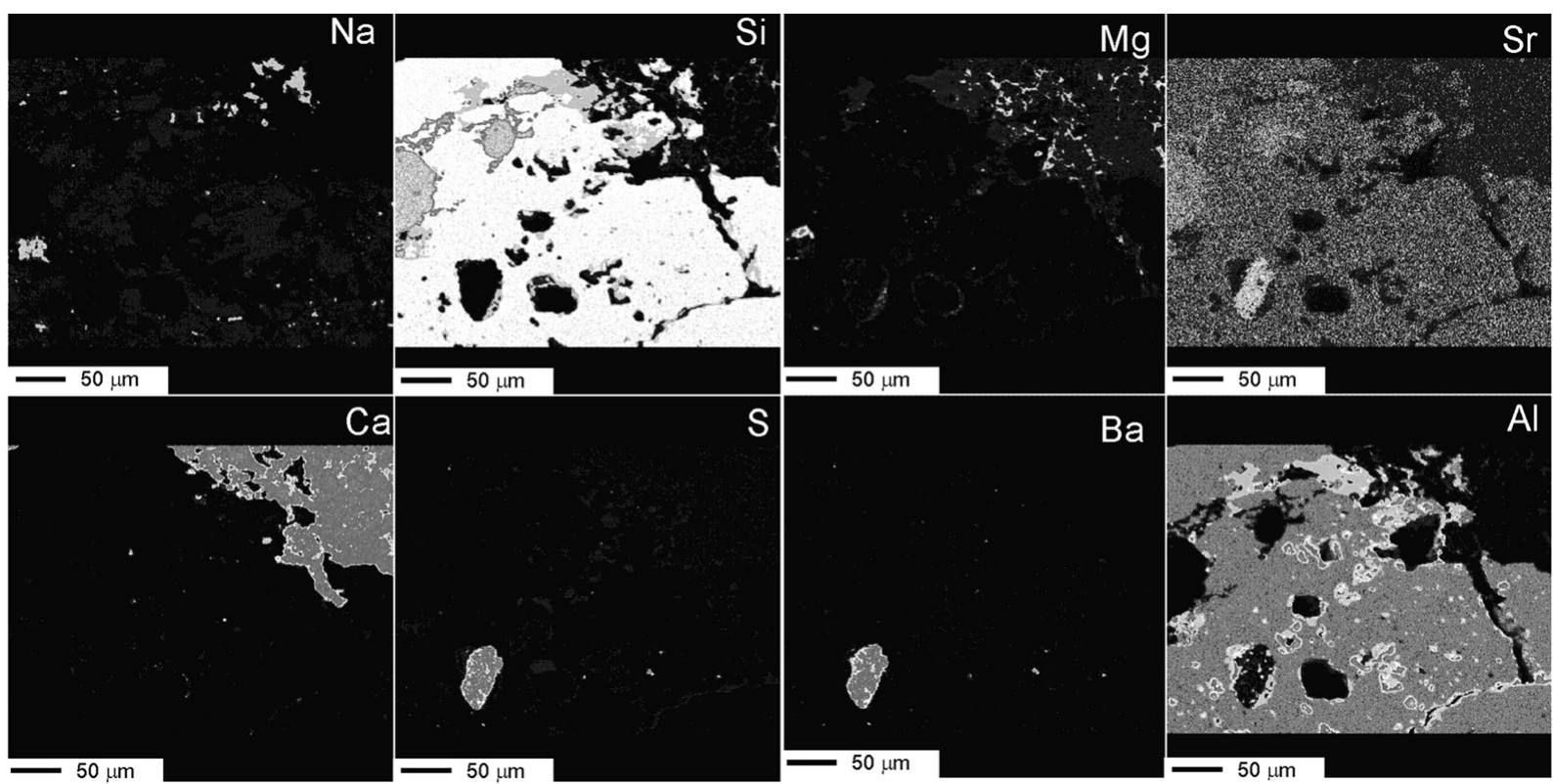

Figure 13. Complementary elemental mapping showing the variation of $\mathrm{Na}, \mathrm{Si}, \mathrm{Mg}, \mathrm{Sr}, \mathrm{Ca}, \mathrm{S}, \mathrm{Ba}$ and $\mathrm{Al}$ and the complex distribution of secondary products inside the weathered mineral. The presence of barite crystals of varied sizes throughout the grain is indicated mostly by the Ba map. Other secondary products are made mostly by $\mathrm{Si}$ or by different mixtures of $\mathrm{Si}, \mathrm{Al}$ and $\mathrm{K}$. Al correlates well with the organic C in the grain (see Fig. 12). See http://journals.cambridge.org/geo for a colour version of this figure.

\section{4.e. Vanished silicates in dolostone and chert beds}

The studied deposits are typically depleted of de-trital silicates as evidenced by XRD mineralogical analyses. When these deposits are examined under the petrographic and fluorescence microscopes, they show scattered silt-sized detrital grains floating in the matrix. In the same size and morphology range as the silicates and exhibiting floating textures, poorly crystalline, mostly fluorescent, components are recognized. Considering textural similarities and occasional silicate relics preserved in the interior, these components have 

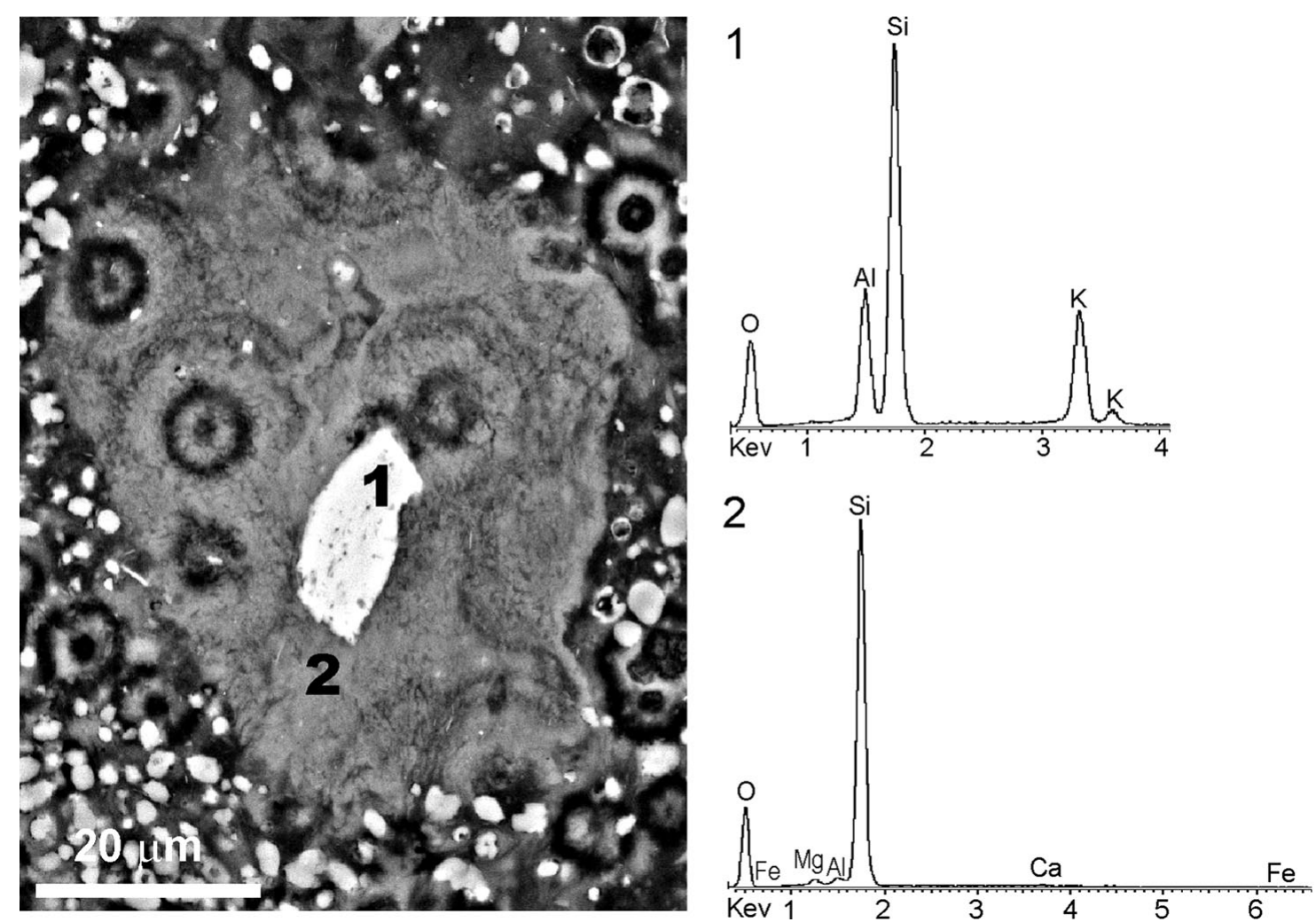

Figure 14. BSE-SEM micrograph of a polished thin-section showing a tabular pseudomorph embedded within a silica matrix, which exhibits a cellular arrangement, and EDS spectra of the components. A relic preserved in the pseudomorph (1) corresponds to K-feldspar. The secondary product after it (2) consists of $\mathrm{Si}$ and $\mathrm{Mg}$, with minor $\mathrm{Al}, \mathrm{Fe}$ and $\mathrm{Ca}$.

been attributed to silicate pseudomorphs. Figure 14 illustrates a tabular silicate pseudomorph embedded in a silica matrix with interspersed dolomite crystals. The interface pseudomorph-matrix is diffuse in some parts. The tabular relic in the interior of the pseudomorph corresponds to potassium feldspar, while the residual product after it consists mainly of silica with $\mathrm{Mg}$, as confirmed by the respective EDS spectra (Fig. 14). The texture of the secondary product imitates closely the cellular arrangement exhibited by the embedding matrix. This suggests that processes involved in the matrix formation are likewise involved in the silicate weathering.

\section{Discussion}

\section{5.a. Evidence for microbial involvement in the weathering processes}

Evidence of the bioweathering of silicate grains is: (1) the occurrence in dolomite and silica microbialites, (2) the presence of typical bioelements $(\mathrm{C}, \mathrm{S}, \mathrm{P})$ associated with the alteration features, (3) the isotope signatures of organic carbon (kerogen), (4) the coexistence of amorphous to poorly-ordered byproducts with variable chemical compositions and (5) the texture of silicate pseudomorphs closely imitating the cellular arrangement exhibited by the embedding matrix.

Sanz-Montero, Rodríguez-Aranda \& García del Cura (2008) interpreted the studied carbonate and chert beds as microbialites resulting from the mineralization of microbial mats that thrived in lake margins. In these sedimentary contexts, the alluvial fans episodically supplied the mudflat-marginal lake fringes with finesized detrital grains that were trapped and bound to the mats. These authors also suggested that the microbial mats thriving in Miocene lacustrine systems provided a template for the dolomite nucleation as the organic matter decayed. Additional observations shown in this paper, concerning the close association of dolomite with organic substrates (Fig. 3), strengthen this interpretation. The isotopic signature $\left(\delta^{13} \mathrm{C}=-24.9 \%\right)$ of the organic carbon (kerogen) from the microbialites is likewise consistent with a biological origin. However, it is not possible to specify the source of kerogen since different carbon fixation pathways have overlapping $\delta^{13} \mathrm{C}$ values (Konhauser, 2007).

Two situations have been found in the surface of the silicates. In the first, the grains occur coated with a film that is interpreted to represent a fossil biofilm. According to Characklis \& Marshall (1990), biological films developed on solid substrates consist of micro-organisms that produce extracellular polymeric substances (EPS) frequently extending out from the cell to form a tangled matrix of fibres as a structural as-semblage. A similar structure has also been recognized in Miocene silicate coatings (see Figs 7, 10). Apart from the significant proportions of $\mathrm{C}$, which are responsible for the fluorescence they emit, the composition of these coatings does not fit any known mineral. In 
detail, the coarsely laminated films show invaginations that reproduce the final sharp-cornered surface of the silicate grains (Fig. 10a). This pattern suggests that biofilm growth was concomitant with the dissolution inwards to the grains and is a demonstration of the weathering syngenicity. Thus, evidence for a biogenic origin of those films comes from their arrangement and structure coupled with the organic carbon content. Hence, in the following, we refer to these coatings as biofilms. The biofilms are enriched in $\mathrm{Si}$ and $\mathrm{Mg}$. This suggests a preferential adsorption of those cations to the exopolymers and is coherent with the cation-binding capability of EPS (Decho, 2000).

In the second situation, spheroidal dolomite and silica crystals with rounded cores corrode and, eventually, replace the silicates (Figs 8, 13). According to Ayll'on-Quevedo et al. (2007) and Sanz-Montero, Rodr'1guez-Aranda \& Garc'1a del Cura (2008), these crystals were precipitated on the microbial cell surfaces and associated polymers, which provided effective nucleation sites for secondary minerals.

An analogous pattern of pitting, corrosion and cracking produced concomitantly with the precipitation of spheroid dolomite crystals has been described in Miocene gypsum beds associated with dolomite microbialites by Sanz-Montero, Rodr'1guezAranda \& Calvo (2006). These authors interpreted the gypsum weathering as being caused by the boring activity of endolithic microbes, presumably cyanobacteria.

Micro-boring of carbonate grains by endolithic cyanobacteria has been largely described in modern marine stromatolites. For instance, McIntyre, PrufertDebout \& Reid (2000) observed that the apical cells of some coccoid cyanobacteria dissolve and penetrate further into carbonate grains at the time the cells are dividing. Along similar lines, Brehm, Gorbushina \& Mottershead (2005) concluded that natural and experimental depression development in silica surfaces corresponded exactly with the outline of micro-organisms or biofilms. These authors observed that bacterial growth accumulations at a single point on the surface of the crystals produce deep pits around each cell.

These observations suggest that silicate dissolution in the Miocene beds was promoted by microbial activity. According to several experiments, microorganisms enhance the weathering of silicate by lowering $\mathrm{pH}$ or by producing ion-complexing organic ligands, or by both (Banfield et al. 1999). Alternatively, microbial production of $\mathrm{OH}^{-}$and subsequent $\mathrm{pH}$ variations may also favour silicate mobilization (Bennett, Rogers \& Choi, 2001). It is difficult to identify the precise micro-organism and mechanisms responsible for the mineral etching in the Miocene samples, although the ubiquitous presence of $\mathrm{S}$ in the weathering products, as both sulphates (barite and, occasionally, celestite) and non-crystalline sulphur, suggests that the mineral etching may have been caused by the microbial communities that play a role in the sulphur cycle. The abundance of calcite pseudomorphs after gypsum suggests that the $\mathrm{S}$ involved in those reactions was derived from the associated gypsum crystals (SanzMontero, Rodríguez-Aranda \& García del Cura, 2005).

\section{5.b. Secondary products}

Microbiogenic minerals are usually amorphous to poorly ordered, with variable chemical compositions, but over time they may transform into crystalline phases having a specific chemical composition (e.g. Kon-hauser, 1998). The secondary products directly related to the Miocene weathered silicate correspond both to crystalline phases, embracing sulphates, silicates and calcite, and to non-crystalline or poorly crystalline products with variable chemical composition. Two or more of these products can coexist in the interior of the altered silicates. Barite has been found to form from the weathering of Babearing feldspar in sulphate-enriched microenvironments, which reflects oxidation processes from sulphur or sulphide to sulphate. Apart from the general context, evidence for a microbial participation in the precipitation of barite comes from the intimate linkage of this mineral with organic $\mathrm{C}$ and with non-crystalline $\mathrm{S}$. Based on experimental studies, a heterotrophic bacterium has been reported to form barite, by exposing it to a solution rich in $\mathrm{Ba}$ (González-Múñoz et al. 2003). Along similar lines, Senko et al.(2004) have reported that barite formation takes place under anoxic conditions due to phototrophic bacterial activity.

It has been shown that barite and secondary quartz coexist inside the same grain (Fig. 11). Quartz, in turn, occurs intermixed with poorly ordered phyllosilicates and with Al-rich amorphous phases. These results reveal the variety of by-products formed from the microbial weathering of a given feldspar grain. Each product is indicative of different microenvironmental conditions, likely produced by microbial reactions, rather than by inorganically driven mechanisms in sedimentary fluids with a specific chemical composition. Therefore, the diversity and proximity of secondary products may be considered as a criterion of bioweathering.

Calcite also occurs as secondary minerals scattered in the weathering fronts of silicate grains. The carbonate is commonly associated with amorphous Alrich compounds. In the microbial context, the localized formation of calcite is due to the creation of alkalinity gradients in response to metabolic processes, while simultaneously attracting $\mathrm{Ca}$ to its organic ligands (Pentecost, 1985). Recently, Benzerara et al. (2005) described the precipitation of calcite in relation to micro-organisms involved in the ongoing weathering of a meteoritic orthopyroxene.

The dissolution of silicates further accounted for the release of significant amounts of $\mathrm{Si}, \mathrm{Al}, \mathrm{K}, \mathrm{Fe}$ and other elements that were susceptible to redistribution. Specifically, the source of silicon in chert interbedded with dolostone in the Miocene lacustrine systems has often been a controversial subject. Our results suggest 
that weathering of the detrital silicates may have supplied the sedimentary system with the Si required for silica precipitation.

\section{5.c. Silicate composition and weathering sequence}

According to Rogers, Bennet \& Choi (1998) and Bennet, Rogers \& Choi (2001), silicate weathering by bacteria is sometimes driven by the nutrient requirements of the microbial consortium and therefore depends on the trace nutrient content of each microen-vironment. Iron is one of the essential nutrients which is often bound as a structural component of silicate minerals. A recent study in Miocene microbialites from the Madrid Basin by Sanz-Montero, Rodr'1guez-Aranda \& P'erez-Soba (2009) has shown that iron-rich phyllosilicates associated with microbial dolomite were both selectively weathered and significantly depleted in iron relative to $\mathrm{Si}$ and $\mathrm{Al}$. This specific weathering pattern was interpreted in terms of a preferential microbial colonization of the Fe-bearing minerals and the concomitant release of this metal that may be used as electron acceptor. Our results indicate that $\mathrm{P}$, which like $\mathrm{S}$ is an essential macronutrient, is present in significant proportions in most of the analysed feldspars (Tables 1,2). Along with Fe, other metals included in the analysed minerals and required for microbial growth are $\mathrm{K}, \mathrm{Mg}$ and $\mathrm{Na}$. Hence, the microbial weathering of silicates may represent a specific strategy offering the colonizing bacteria a competitive ecological advantage, as pointed out by Bennet, Rogers \& Choi (2001). Nevertheless, the chemical composition does not explain the microbial attachment and weathering exhibited by quartz grains. Alternatively, the weathering of quartz may be due to the coincidental result of microbial metabolism.

Sanz-Montero \& Rodr'1guez-Aranda (2007) described similar silicate weathering sequences in thick and laterally continuous dolomite successions from the continental Madrid Basin. Those successions are separated temporally and spatially from the ones studied here, but the weathering features are quite uniform and hence significantly representative. The development and preservation of similar dissolutional features in different stratigraphic successions suggests that silicate bioweathering may have had major implic-ations in the recycling of minerals within continental basins over geological time. Thus, the rock record provides information for understanding microbial-mineral interactions.

\section{Conclusions}

Thick and laterally continuous dolomite-bearing successions from the Miocene Duero Basin record the geochemical cycles of silicate weathering and subsequent precipitation of secondary products, including minerals and intermediate substances. These backfeeding mechanisms were coeval with the precipitation of dolomite. Isotopic, chemical and textural evidence indicates the mediation of micro-organism in these processes. Accordingly, the weathering features coupled with specific secondary mineral assemblages can be useful biosignatures. Weathering textures range from surface etching and pitting to extensive disaggregation of the minerals and may have even caused the complete destruction of the silicate grains. The secondary products found directly related to the weathered silicates correspond both to crystalline phases (sulphates, silicates and carbonates) and to non-crystalline or poorly crystalline products with variable chemical composition. The coexistence of byproducts with diverse crystallinity and chemical composition is suggested as a criterion of biogenicity. The abundance of deeply weathered grains further indicates that silicate dissolution may have supplied the system with the silica required for the formation of interbedded chert. Thus, bioweathering of silicates may have had broad implications in the recycling of minerals within mixed microbial carbonate/ siliciclastic deposits over geological time.

The results demonstrate that the rock record provides a wide range for detection and characterization of mineral-microbe interactions in lacustrine microbial mats.

Acknowledgements. This work was supported by the Projects PR45/05-14165 (Madrid Community) and PR34/07- 15900 (Santander/Complutense). We thank Dr A. Pentecost and two anonymous reviewers for their comments and suggestions that led to the improvement of this manuscript.

\section{References}

Armenteros, I., Corrochano, A., Alonso-Gavilán, G., CARballeira, J. \& Rodríguez, J. M. 2002. Duero basin (northern Spain). In The Geology of Spain (eds W. Gibbons \& M. T. Moreno), pp. 309-15. London: The Geological Society.

AYllón-Quevedo, F., SouZA-EgIPSY, V., SANZ-Montero, M. E. \& RoDRÍGUEZ-ARANDA, J. P. 2007. Fluid Inclusion analysis of twinned selenite gypsum beds from the Miocene of the Madrid Basin (Spain). Implication on Dolomite Bioformation. Sedimentary Geology 201, 212-30.

BANFIELD, J. F., BARKER, W. W., WELCH, S. A. \& TAUNTON, A. 1999. Biological impact on mineral dissolution: Application of the lichen model to understanding mineral weathering in the rhizosphere. Proceedings National Academy of Science USA 96, 3404-11.

BARKER, W. W., WelCh, S. A. \& BANFIELD, J. F. 1997. Geomicrobiology: Interactions between microbes and minerals. In Geomicrobiology of silicate mineral weathering (eds J. F. Banfield \& K. H. Nealson), pp. 391-428. Reviews in Mineralogy 335.

BARKer, W. W., Welch, S. A., Chu, S. \& BANFIELD, J. F. 1998. Experimental observations of the effects of bacteria on aluminosilicate weathering. American Mineralogy 83, 1551-63.

Bennett, P. C., Rogers, J. R. \& Choi, W. J. 2001. Silicates, silicate weathering, and microbial ecology. Geomicrobiology Journal 18, 3-19.

Benzerara, K., YoOn, T. H., Menguy, N., Tyliszczak, T. \& BRown, G. E. 2005. Nanoscale environments 
associated with bioweathering of a $\mathrm{Mg}$-Fe-pyroxene. Proceedings National Academy of Science USA 25, 97982.

Berner, R. A., Lasaga, A. C. \& Garrells, R. M. 1983. The carbonate-silicate geochemical cycle and its effect on atmospheric carbon dioxide over the past 100 million years. America Journal of Science 283, 641-83.

BreHM, U., GorbushinA, A. \& MotTERSHEAD, D. 2005. The role of microorganisms and biofilms in the breakdown and dissolution of quartz and glass. Palaeogeography, Palaeoclimatology, Palaeoecology 219, 117-29.

Characklis, W. G. \& MARshall, K. C. 1990. Biofilms: a basis for an interdisciplinary approach. In Biofilms (eds W. G. Characklis \& K. C. Marshall), pp. 3-15. New York: Wiley Interscience.

DAVIS, K. J. \& LÜTTGE, A. 2005. Quantifying the relationship between microbial attachment and mineral surface dynamics using vertical scanning interferometry (VSI). America Journal of Science 305, 727-51.

DeCHO, A. W. 2000. Microbial biofilms in intertidal systems: an overview. Continental Shelf Research 20, $1257-73$

DonG, H. L., KostKa, J. E. \& KiM, J. 2003. Microscopic evidence for microbial dissolution of smectite. Clays and Clay Minerals 51, 502-12.

EHRLICH, H. L. 1996. How microbes influence mineral growth and dissolution. Chemical Geology 132, 5-9.

FLETCHER, M. \& MURPHY, E. 2001. Transport of microorganisms in the subsurface: the role of attachment and colonization of particles surfaces. In Subsurface microbiology and biogeochemistry (eds J. K. Fredrickson \& M. Fletcher), pp. 39-68. New York: John Wiley and Sons, Inc.

GONZÁLEZ-MúÑoZ， M. T., FERNÁNDEZ-LuQuE， B., Martínez-Ruíz, F., CheKroun, K. B., Arias, J. M., RODRÍGUEZ-GALLEGO, M., MARTÍNEZ-CAÑAMERO, M., LINARES, C. \& ADINA, P. 2003. Precipitation of Barite by Myxococcus Xanthus: Possible Implications for the Biogeochemical Cycle of Barium. Applied and Environmental Microbiology 69, 5722-5.

KONHAUSER, K. O. 1998. Diversity of bacterial iron mineralization. Earth-Science Reviews 43, 91-121.

KONHAUSER, K. O. 2007. Introduction to geomicrobiology. Blackwell Publishing, 425 pp.

Konhauser, K. O. \& Ferris, F. G. 1996. Diversity of iron and silica precipitation by microbial biofilms in hydrothermal waters, Iceland: implications for Precambrian iron formations. Geology 24, 323-6.

Mcintyre, I. G., Prufert-Debout, L. \& Reid, R. P. 2000. The role of endolithic cyanobacteria in the formation of lithified laminae in Bahamian stromatolites. Sedimento$\log y$ 47, 915-21.

PenteCost, A. 1985. Association of cyanobacteria with tufa deposits: identity, enumeration, and nature of the sheath material revealed by histochemistry. Geomicrobiology Journal 4, 285-98.

RODRÍGUEZ-ARANDA, J. P. \& CALVO, J. P. 1998. Trace fossils and rhizoliths as a tool for sedimentological and palaeoenvironmental analysis of ancient continental evap- orite successions. Palaeogeography, Palaeoclimatology, Palaeoecology 140, 383-99.

Rogers, J. R., BENNET, P. C. \& ChOI, W. J. 1998. Feldspars as a source of nutrients for microorganisms. American Mineralogist 83, 1532-40.

SANZ-MonTERO, M. E. \& RodríGUEZ-ArandA, J. P. 2007. Microbial weathering of silicates in dolomiteprecipitating environments. Miocene lacustrine deposits from the Duero and Madrid Basins, Spain. European Research Abstracts 9, A-06310.

SANZ-MONTERO, M. E., RodRÍGUEZ-ARANDA, J. P. \& CALVO, J. P. 2006. Mediation of endoevaporitic microbial communities in early replacement of gypsum by dolomite. A case study from Miocene lake deposits of the Madrid Basin, Spain. Journal of Sedimentary Research 76, 1257-66.

SANZ-Montero, M. E., Rodríguez-ArandA, J. P. \& García Del CurA, M. A. 2005. Texturas diagenéticas de calcita desarrolladas sobre facies dolomíticas microbianas en el Mioceno de la Cuenca del Duero (Zona de Cuéllar). Macla 3, 193-5.

SANZ-MONTERO, M. E., RodrígueZ-ArandA, J. P. \& García Del CurA, M. A. 2008. Dolomite-silica stromatolites in Miocene lacustrine deposits from the Duero Basin, Spain. The role of organotemplates in the precipitation of dolomite. Sedimentology 55, 729-50.

SANZ-MONTERO, M. E., RODRÍGUEZ-ARANDA, J. P. \& PÉREZ-SOBA, C. 2009. Microbial weathering of Fe-rich phyllosilicates and formation of pyrite in the dolomiteprecipitating environment of a Miocene lacustrine system. European Journal of Mineralogy, in press. DOI: 10.1127/0935-1221/2009/0021-1877.

SENKO, J. M., CAMPBEll, B. S., HENRIKSEN, J. R., ElSAHED, M. S., Dewers, T. A. \& Krumholz, L. R. 2004. Barite deposition resulting from phototrophic sulfide-oxidizing bacterial activity. Geochimica et Cosmochimica Acta $\mathbf{6 8}$, 773-80.

STUCKI, J. W., BAILEY, G. W. \& GAN, H. M. 1996. Oxidationreduction mechanisms in iron-bearing phyllosilicates. Applied Clay Science 10, 417-30.

Ullman, W. J. \& WelCH, S. A. 2002. Weathering. Mineral Dissolution and microbial metabolism. In Encyclopedia of environmental microbiology, vol. 6 (ed. G. Bitton), pp. 3375-89. New York: John Wiley and Sons, Inc.

Urrutia, M. M. \& Beveridge, T. J. 1994. Formation of fine-grained metal and silicate precipitates on a bacterial surface (Bacillus subtilis). Chemical Geology 116, 26180.

Vandevivere, P., Welch, S. A., Ullman, W. J. \& KIRCHMAN, D. L. 1994. Enhanced dissolution of silicate minerals by bacteria at near-neutral $\mathrm{pH}$. Microbial Ecology 27, 241-51.

WELCH, S. A., BARKER, W. W. \& BANFIELD, J. F. 1999. Microbial extracellular polymers and plagioclase dissolution. Geochimica et Cosmochimica Acta 63, 1405-19.

Welch, S. A. \& Ullman, W. J. 1992. The effect of soluble organic acids on feldspar dissolution rates and stoichiometry. Geochimica et Cosmochimica Acta 57, 2725-36. 